\title{
Evaluation of Cowpea (Vigna unguiculata L.walp) Genotypes for Biological Nitrogen Fixation in Maize-cowpea Crop Rotation
}

\author{
Simunji Simunji ${ }^{1}$, Kalaluka L. Munyinda ${ }^{1}$, Obed I. Lungu ${ }^{2}$, Alice M. Mweetwa ${ }^{2} \&$ Elijah Phiri ${ }^{2}$ \\ ${ }^{1}$ The University of Zambia, School of Agriculture Sciences, Department of Plant Science, P.O Box, 32379 \\ Lusaka, Zambia \\ ${ }^{2}$ The University of Zambia, School of Agriculture Sciences, Department of Soil Science, P.O Box, 32379 Lusaka, \\ Zambia \\ Correspondence: Simunji Simunji, The University of Zambia, School of Agriculture Sciences, Department of \\ Plant Science. P.O Box, 32379 Lusaka, Zambia. Tel: 260-125-0587/291-777
}

Received: November 2, 2018 Accepted: November 23, 2018 Online Published: January 25, 2019

doi:10.5539/sar.v8n1p82 URL: https://doi.org/10.5539/sar.v8n1p82

\begin{abstract}
Nitrogen is a major plant nutrient which is most limiting in the soil due to soil losses of mineral nitrogen $(\mathrm{N})$ form. To ensure availability of nitrogen in the soil, the study was conducted to screen four cowpea genotypes for Biological Nitrogen Fixation (BNF) and their contribution to maize yield in maize- cowpea rotation. The cowpea genotypes used were mutants LT11-3-3-12 (LT) and BB14-16-2-2 (BB) and their parental varieties Lutembwe (LTPRT) and Bubebe (BBPRT) respectively. Trials were established at two sites (Chisamba and Batoka) of different soil types. The Randomized Complete Block Design (RCBD) with three replications was used. Labelled ${ }^{15} \mathrm{~N}$ urea was applied at $20 \mathrm{kgNha}^{-1}$ on the four cowpea genotypes during 2015/16 growing season. Cowpea plant parts were dried and milled for ${ }^{15} \mathrm{~N}$ isotopic analysis. The data collected included Nitrogen content and atom $\%{ }^{15} \mathrm{~N}$ excess in the fixing cowpea genotypes and non-nitrogen fixing pearl millet to determine total nitrogen derived from the atmosphere (TNdfa) and total nitrogen (TN) in plant parts which were further used to compute Biological Nitrogen Fixation (BNF). The results showed that BNF by cowpea genotypes at Chisamba was $63.9 \mathrm{~kg} \mathrm{ha}^{-1}$ and was significantly $(\mathrm{P}<0.001)$ more than BNF of $6.6 \mathrm{kgha}^{-1}$ at Batoka. The LT mutant fixed significantly $(\mathrm{P}<0.001)$ higher nitrogen of $86.1 \mathrm{kgha}^{-1}$ and $16.5 \mathrm{~kg} \mathrm{ha}^{-1}$ at Chisamba and Batoka respectively than other genotypes. However, both BB and LT mutants significantly fixed more nitrogen than their parents and have demonstrated to increase maize grain yields up-to $12 \mathrm{tha}^{-1}$ in the maize - cowpea rotation.
\end{abstract}

Keywords: biological nitrogen fixation, cowpea genotype, maize- cowpea rotation, nitrogen

\section{Introduction}

Cowpea (Vigna unguiculata) is one of the main legumes contributing to the economy of nitrogen in the cropping systems with low input through the Biological Nitrogen Fixation (BNF)(Sanginga, Lyasse, \& Singh, 2000). The crop may contribute some of the acquired nitrogen to soil organic matter and nitrogen needs of succeeding and associated crops (International Atomic Energy Agency (IAEA), 2008). The symbiotically nitrogen can reduce the rate of soil degradation where legume-cereal rotations are practiced. The amounts of nitrogen contributed by various legumes that include cowpea vary between 50-300 $\mathrm{kgha}^{-1}$ per year. These values will depend on the legume species, plant densities, cropping system and legume genotypes. (Makoi, Chimphango, \& Dakora, 2009). Awonaike, Kumarasinghe and Danso (1990) reported the BNF of Cowpea being between $74 \mathrm{kgNha}^{-1}$ to 116 $\mathrm{kgNha}^{-1}$. Cowpea varieties vary in nitrogen fixation potential due to differences in the number, weight, efficiency of nodules and farming systems (Makoi et al., 2009). Cowpea - maize rotation tend to increase soil fertility after a season of rotation. Jeranyama, Hesterman' Waddington and Harwood (2000) indicated that maize produced after cowpea yielded $1940 \mathrm{kgha}^{-1}$ as compared to the control which had $1220 \mathrm{kgha}^{-1}$. Maize/ Cowpea rotation was reported by Hardter, Harst Schmidt and Frey, (1991) to produce highest maize grain yield compared to mono-cropping due to BNF. In order to intensify the cereal production, additional amounts of nitrogen are necessary to maintain the soil fertility in the maize - legume rotation systems. According to Fujita et al, 1990, leguminous crops are sources of nitrogen and contribute to an increase in the nitrogen uptake of the nonleguminous associated crops. While Senaratne, Liyanage and Soper, (1995) indicated that $161 \mathrm{mg} \mathrm{Nplant}^{-1}$ were fixed by intercropped cowpea which obtained $81 \%$ of its $\mathrm{N}$ derived from atmosphere. 
The soils in Zambia are however, been reported to have inherently poor fertility status and are most vulnerable to degradation upon cultivation. Due to poor soil fertility, productivity of maize which is a staple food among the smallholder farmers has become very low, ranging from 1.1 tha $^{-1}$ to 2.3 tha $^{-1}$. These yields are very low when viewed against average potential yield of maize which is currently at 10 tha $^{-1}$ (Indaba Agricultural Policy Research Institute (IAPRI), 2015). One of the major limiting factors is insufficient nitrogen nutrient in the soil because of leaching and volatilization. However, yields of maize can be increased by use of improved and sustainable farming system where the maize crop is rotated with legume crop that fixes nitrogen in the soil. Soil quality can therefore be efficiently, sustainably and effectively managed with the use of newly adapted technologies to improve the production potential in appropriate systems. Some of these systems include crop rotations of cereal crops with legumes such as cowpeas that can fix substantial amount of nitrogen (Phiri, Chipeleme \& Chabala, 2006). Therefore, Screening of cowpea genotypes that have high potential for nitrogen fixation and at the same time have a low proportion of $\mathrm{N}$ derived from the soil should be a priority for farmers.

The University of Zambia in the recent years have produced some cowpea mutants from the two released parent cowpea varieties that have not been evaluated for biological nitrogen fixation. There is no information documented on the ability of cowpea varieties and their mutants to fix nitrogen in the soil in Zambia. This study was therefore conducted with an objective to evaluate the released cowpea genotypes for biological nitrogen fixation and their contribution to maize productivity of maize grain in a rotation with the legumes.

\section{Materials and Methods}

The study was conducted to screen four screening four cowpea genotypes for biological nitrogen fixation and their contribution to the yields of maize grown as subsequent crop in a rotation.

\subsection{Location of Experiments}

The study was conducted at two sites at Chisamba S $14.96783^{\circ}$, E $028.09408^{\circ}$; and Batoka S16.79993 ${ }^{\circ}$ E $027.20181^{\circ}$ both in region II of the Zambian agro-ecological zones. Chisamba is located in the central province of Zambia about $65 \mathrm{~km}$ north of Lusaka the capital city. Batoka is located in the Southern Province, about 300 $\mathrm{km}$ from Lusaka. The Chisamba site is characterized by Clay Loam soils while Batoka site by Loamy Sand soils.

Table 1. Baseline Soil chemical properties of the sites+

\begin{tabular}{|c|c|c|c|c|c|c|c|c|c|c|}
\hline $\begin{array}{l}\text { Farming } \\
\text { Systems }\end{array}$ & Site & Depth & $\mathrm{pH}$ & $\mathrm{OM}$ & $\mathrm{N}$ & $\mathrm{P}$ & K & $\mathrm{Ca}$ & $\mathrm{Mg}$ & $\mathrm{Zn}$ \\
\hline & & $\mathrm{Cm}$ & & c & $\%$ & $\mathrm{mg} / \mathrm{kg}$ & & $\mathrm{cmol} / \mathrm{kg}$ & & $\mathrm{mg} / \mathrm{kg}$ \\
\hline $\mathrm{CONV}$ & Batoka & $0-15$ & 4.12 & 1.68 & 0.08 & 17.4 & 0.1 & 1.27 & 0.29 & 0.04 \\
\hline CONV & Batoka & $15-30$ & 4.31 & 0.96 & 0.06 & 14.62 & 0.08 & 1.78 & 0.37 & 0.06 \\
\hline $\mathrm{CF}$ & Batoka & $0-15$ & 3.8 & 0.64 & 0.03 & 34.06 & 0.1 & 1.66 & 0.19 & 0.24 \\
\hline $\mathrm{CF}$ & Batoka & $15-30$ & 3.71 & 1.12 & 0.03 & 37.88 & 0.08 & 0.93 & 0.11 & 0.14 \\
\hline CONV & Chisamba & $0-15$ & 6.17 & 0.72 & 0.05 & 17.92 & 1.04 & 10.9 & 5.48 & 0.28 \\
\hline CONV & Chisamba & $15-30$ & 6.2 & 2.72 & 0.09 & 17.86 & 0.78 & 10.92 & 5.76 & 0.12 \\
\hline $\mathrm{CF}$ & Chisamba & $0-15$ & 5.49 & 3.2 & 0.05 & 18.86 & 1.11 & 8.59 & 4.4 & 0.28 \\
\hline $\mathrm{CF}$ & Chisamba & $15-30$ & 5.58 & 2.72 & 0.08 & 13.15 & 0.83 & 8.98 & 5.01 & 0.20 \\
\hline
\end{tabular}

Based on the baseline soil analysis, soil fertility at Batoka is generally lower as compared to Chisamba. pH, Organic matter, Potassium, Calcium, Magnesium and Zinc at Batoka were on average 4.0, $1.2 \%, 0.1 \mathrm{cmol}$, $1.41 \mathrm{cmol} / \mathrm{kg}, 0.32 \mathrm{cmol} / \mathrm{kg}, 0.16 \mathrm{mg} / \mathrm{kg}$ respectively whereas Chisamba had 5.6, 2.7\%, $1.0 \mathrm{cmol} / \mathrm{kg}, 9.9 \mathrm{Ca}$ $\mathrm{cmol} / \mathrm{kg}, 5.16 \mathrm{cmol} / \mathrm{kg}$ and $0.22 \mathrm{mg} / \mathrm{kg}$ (Table 1). The average annual rain fall at both sites is $750 \mathrm{~mm}$. During the 2015/2016 growing season, Chisamba received $726.6 \mathrm{~mm}$ of rainfall while Batoka had $620.5 \mathrm{~mm}$.

\subsection{Source of Cowpea Genotypes Seed}

The four cowpea genotypes evaluated for Biological Nitrogen Fixation (BNF) in the maize- cowpea rotation system were two parents, Bubebe (BBPRT) and Lutembwe (LTPRT) and two mutants LT 11-3-3-12 (LT) and BB 
14-16-2-2 (BB) one from each parent respectively. The seed was supplied by the University of Zambia, School of Agricultural Sciences, and Department of Plant Science.

\subsection{Experimental Design}

The experiment was laid out in a Randomized Complete Block Design (RCBD) with three replications. The four cowpea genotype treatments BBPRT, LTPRT and LT and BB were replicated three times.

\subsection{Trial Establishment and Crop Management}

Cowpea genotypes were planted under minimum tillage practice as one of the conservation farming principles during the 2014/15 and 2015/2016 growing seasons. Planting was done by hand through drilling along the ripped furrows at seed rate of $30 \mathrm{~kg} \mathrm{ha}^{-1}$ to about $7 \mathrm{~cm}$ between seeds The plot was applied compound fertilizer $10 \% \mathrm{~N}$ : $20 \% \mathrm{P}: 10 \% \mathrm{~K}$ at $200 \mathrm{kgha}^{-1}$ providing $20 \mathrm{kgha}^{-1}$ nitrogen, $40 \mathrm{kgha}^{-1} \mathrm{P}_{2} \mathrm{O}_{5}$ and $20 \mathrm{kgha}^{-1} \mathrm{~K}_{2} \mathrm{O}$ at planting. Each plot of cowpea crop had 12 rows of $6 \mathrm{~m}$ length spaced at $0.75 \mathrm{~m}$. Two guard rows at each end of the blocks were included. ${ }^{15} \mathrm{~N}$ labelled urea was applied to all treatment plots on $1.5 \mathrm{~m}^{2}$ two weeks after planting for determination of Biological Nitrogen Fixation. The application rate was $6.42 \mathrm{~g}$ urea $\left(20 \mathrm{kgN} \mathrm{ha}{ }^{-1}\right)$ of $5.2 \mathrm{atom} \%$ ${ }^{15} \mathrm{~N}$ per sub plot of $1.5 \mathrm{~m}^{2}$ (Freitas, Silva \& Sampaio, 2012) The application was done using a knapsack sprayer.

Two separate sprays against pests and diseases were made. The first control was at two weeks after cowpea emergency and the second at flowering stage. At planting, Glyphosate spray was applied targeting emerged weeds in the trial field. The next weeding was done manually twice at two and four weeks after planting.

Eight net rows of cowpea were harvested to determine dry biomass and grain yields at maturity stage. The $500 \mathrm{~g}$ sample of cowpea stover was dried in an oven at $80{ }^{\circ} \mathrm{C}$ for $48 \mathrm{hrs}$. Sample dry weight was used to convert plot wet weight to dry weight. Cowpea stover, pods and grain used in the assessment of nitrogen uptake were sampled at harvest from $1 \mathrm{~m}$ of the middle row of the labelled ${ }^{15} \mathrm{~N}$ subplot. The stover was dried in an oven at 80 ${ }^{\circ} \mathrm{C}$ for $48 \mathrm{hrs}$. Stover, pods and grains were then milled. The samples were stored in the fridge at $18{ }^{\circ} \mathrm{C}$ before analysis. Isotopic analysis on the samples was done at University of Florida and facilitated by International Atomic Energy Agency, Vienna.

\subsection{Maize- Cowpea Rotations}

In year $2(2015 / 2016)$ season maize varieties were planted after the cowpea genotypes to determine the effect of cowpea on maize productivity in the rotation as compared to maize mono cropping system(CONV) under conventional in the published paper "Optimizing Soil Moisture and Nitrogen Use Efficiency of Some Maize (Zea mays) Varieties under Conservation Farming System (Simunji et al, 2018).

\subsection{Data Collection}

The data collected during crop growth were $50 \%$ flowering, $50 \%$ podding, $90 \%$ physiological maturity, dry biomass and grain yields. The laboratory data collected included atom $\%{ }^{15} \mathrm{~N}$ excess and nitrogen content. The weighted atom $\%{ }^{15} \mathrm{~N}$ was calculated from analysed atom $\%{ }^{15} \mathrm{~N}$ excess of cowpea dry biomass, pods and grains. The extent of nitrogen fixation(NF) was computed based on the difference between atom $\%{ }^{15} \mathrm{~N}$ of the parent cowpea to its mutant. Biological Nitrogen Fixation (BNF) was estimated as \% nitrogen derived from atmosphere (\% Ndfa) using N- Isotope dilution technique equation of Hardason and Danso, (1990).

$$
\% \mathrm{Ndfa}=[1-(\mathrm{Nfix} / \mathrm{Nref}) \mathrm{x} 100]
$$

Where Nfix is ${ }^{15} \mathrm{~N}$ atom $\%$ excess of the $\mathrm{N}$ - fixing plant and Nref is the ${ }^{15} \mathrm{~N}$ atom $\%$ excess of the non-fixing plant (pearl millet). The lower the ${ }^{15} \mathrm{~N}$ atom\% excess in the plant the higher BNF of the plant due to dilution caused by Ndfa (IAEA, 2008). The extent to which the ${ }^{15} \mathrm{~N} /{ }^{14} \mathrm{~N}$ ratio decreases in the fixing crop, relative to the nonfixing plant determines BNF (Montañez \& Sicardi, 2013). Nitrogen (N) content in the cowpea dry biomass, grain and pod was analysed and were used to compute total $\mathrm{N}(\mathrm{TN})$ accumulated in the dry biomass, grain and pod yields, while $\mathrm{N}$ fixed was calculated using the formula.,

$$
\text { Nfixed }=(\% N d f a) \times T N
$$

Where Nfixed is nitrogen fixed and TN is total $\mathrm{N}$ in the dry biomass, grain and pod. The Nitrogen Harvest Index (NHI) which is the proportion of the $\mathrm{N}$ in the grain to the total above ground was computed and compared to Ndfa for determination of $\mathrm{N}$ pool in the soil according to Giller and Wilson, (1995).

The computed data values of weighted atom $\%{ }^{15} \mathrm{~N}$, Ndfa, Nfixed and NHI were statistically analysed for standard error mean separation with the help of Genstat $18^{\text {th }}$ edition software. 


\section{Results and Discussion}

\subsection{Weighted Atom $\%{ }^{15} \mathrm{~N}$}

The weighted nitrogen atom $\%{ }^{15} \mathrm{~N}$ which was calculated from the atom $\%{ }^{15} \mathrm{~N}$ of the stover, pods and grain showed significant variation between the two sites and among the cowpea genotypes. The weighted atom $\%{ }^{15} \mathrm{~N}$ for Chisamba was on average 0.4 while for Batoka was 0.63 . The values indicated that Chisamba was $58 \%$ atom $\%{ }^{15} \mathrm{~N}$ significantly $(\mathrm{P}<0.01)$ lower than Batoka (Figure 1).

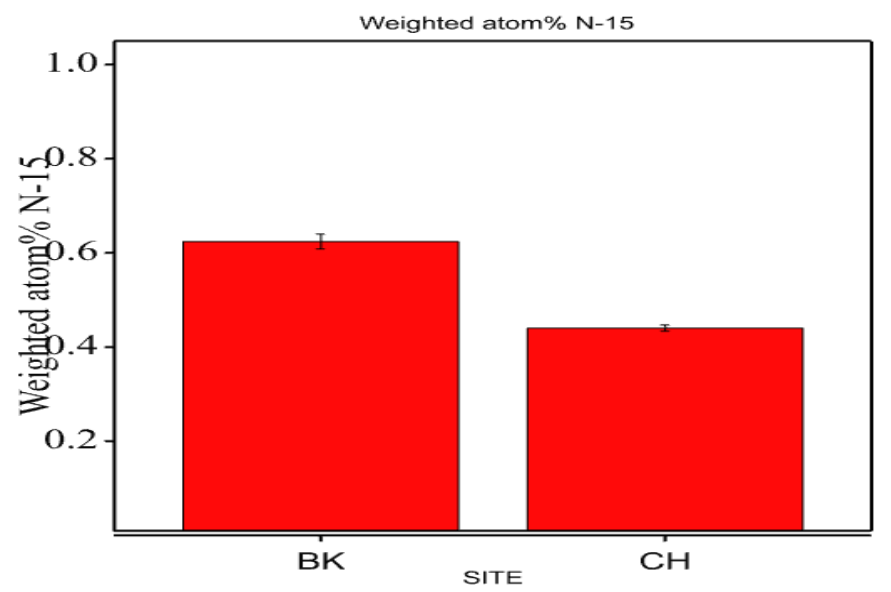

Figure 1. Effect of sites on Cowpea Nitrogen fixation by weighted atom $\%{ }^{15} \mathrm{~N}$

The difference in the weighted atom $\%{ }^{15} \mathrm{~N}$ at two sites was significant at $\mathrm{P}<0.01$ ). IAEA. (2008) reported that the lower the atom $\%{ }^{15} \mathrm{~N}$ in the sample analysis the higher the Biological Nitrogen Fixation (BNF) due to dilution of nitrogen from the atmosphere. Therefore the data showed that Chisamba site had higher BNF than Batoka site. Chisamba site has Clay Loam soils and is rich in most of the essential plant nutrients as compared to Batoka with poor Loamy Sand soils. Biological nitrogen fixation by legumes is usually enhanced by availability of rhizobium bacteria and phosphorus nutrient in the soil. Carsky et al. (2001) reported low Ndfa in very early maturing local cowpea varieties on relatively poor soils while Sanginga et al. (2000) found increased nitrogen balance in the soil with application of phosphorus. This showed that the high BNF determined at Chisamba could be attributed to high levels of rhizobium bacteria, high $\mathrm{pH}$ (5.6) and high levels phosphorus in the soil (Table 1\&2).

Table 2. Soil chemical status between the two sites and among Cowpea genotypes $(0-15 \mathrm{~cm})$

\begin{tabular}{llllll}
\hline Main treatments & $\begin{array}{l}\mathbf{p H} \\
\mathbf{C a C l}_{\mathbf{2}}\end{array}$ & $\begin{array}{l}\mathbf{C} \\
\mathbf{\%}\end{array}$ & $\begin{array}{l}\mathbf{C a} \\
\mathbf{m g k g}\end{array}$ & $\begin{array}{l}\mathbf{P} \\
\mathbf{m g k g}^{-1}\end{array}$ & $\begin{array}{l}\mathbf{N} \\
\mathbf{\%}\end{array}$ \\
\hline Chisamba (CH) & 6.73 & 0.76 & 218.5 & 76.50 & 0.037 \\
Batoka ( BK) & 4.44 & 0.54 & 112.6 & 10.80 & 0.042 \\
LsD (0.05) & 0.215 & 0.11 & 13.83 & 4.21 & 0.00535 \\
CV \% & 5.0 & 22.20 & 10.9 & 12.60 & 17.7 \\
\hline Sub Treatments & & & & & \\
BB & 5.46 & 0.71 & 165.4 & 50.70 & 0.047 \\
BBPRT & 5.56 & 0.72 & 178 & 31.70 & 0.038 \\
LT & 5.39 & 0.81 & 168.1 & 46.70 & 0.055 \\
LTPRT & 5.64 & 0.50 & 197 & 57.00 & 0.029 \\
CONV & 5.88 & 0.41 & 119.1 & 32.00 & 0.028 \\
LsD (0.05) & 0.34 & 0.18 & 21.87 & 6.65 & 0.00846 \\
CV \% & 5.0 & 22.20 & 10.9 & 12.6 & 17.7 \\
\hline
\end{tabular}

Among the genotypes evaluated for BNF, LT had lowest weighted atom $\%{ }^{15} \mathrm{~N}$ of 0.55 at Batoka and 0.42 at Chisamba compared to other genotypes. This was followed by LTPRT with 0.60 at Batoka and 0.47 at Chisamba. On average LT fixed a $10.3 \%$ significantly lower at $(\mathrm{P}<0.001)$ than its parent LTPRT. The BB was $4.6 \%$ significantly lower in the weighted atom $\%{ }^{15} \mathrm{~N}$ than the parent BB PRT (Figure 2). 


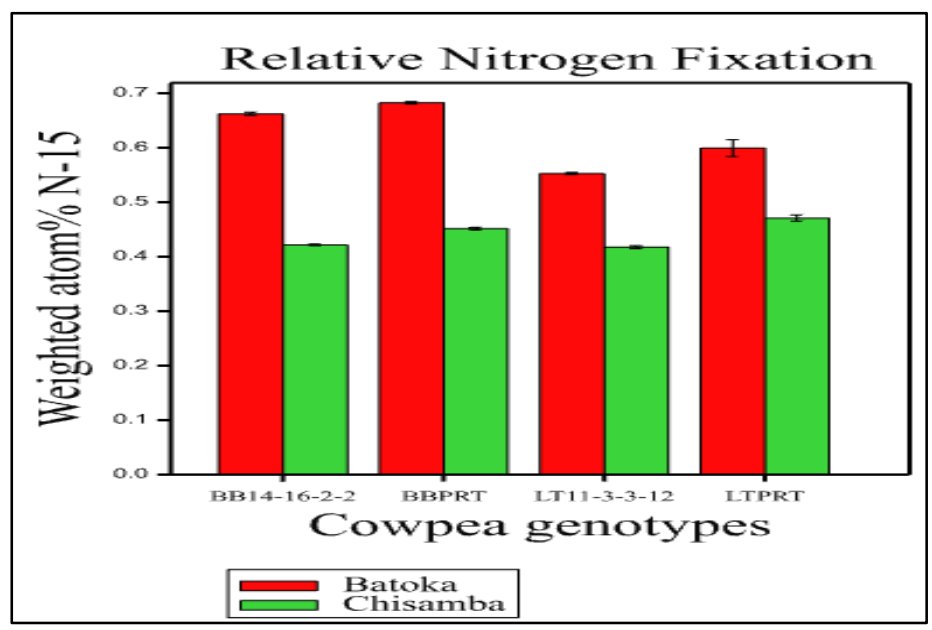

Figure 2. Weighted atom $\%{ }^{15} \mathrm{~N}$ of the cowpea genotypes

The results suggested that $\mathrm{BB}$ and $\mathrm{LT}$ mutants fixed more nitrogen than their respective parent varieties. The results further revealed that parent LTPRT and its mutant LT had better traits for BNF than BBPRT and its mutant BB. The findings were in agreement with Sanginga et al. (1990) and Makoi et al. (2009) who indicated that there was genetic variability among and within legumes. An interaction in atom $\%{ }^{15} \mathrm{~N}$ between the sites and the cowpea genotypes was observed. The LT mutant was more stable and fixed more nitrogen at both sites while BB mutant tended to fix more nitrogen at Chisamba which has Clay Loam soils.

\subsection{Extent of Nitrogen Fixation}

The extent of Nitrogen Fixation(NF) was computed based on the difference between atom $\%{ }^{15} \mathrm{~N}$ of the parent cowpea to its mutant. The mutants were superior over their parents in terms of atom $\%{ }^{15} \mathrm{~N}$ but the extent of NF $\%$ between them varied. BB was $3.0 \%$ and LT was $8.0 \%$ over their parents BBPRT and LTPRT respectively at Batoka with Loamy Sand soils. At Chisamba, BB and LT were $6.0 \%$ and $11.0 \%$ respectively ( Figure 3).

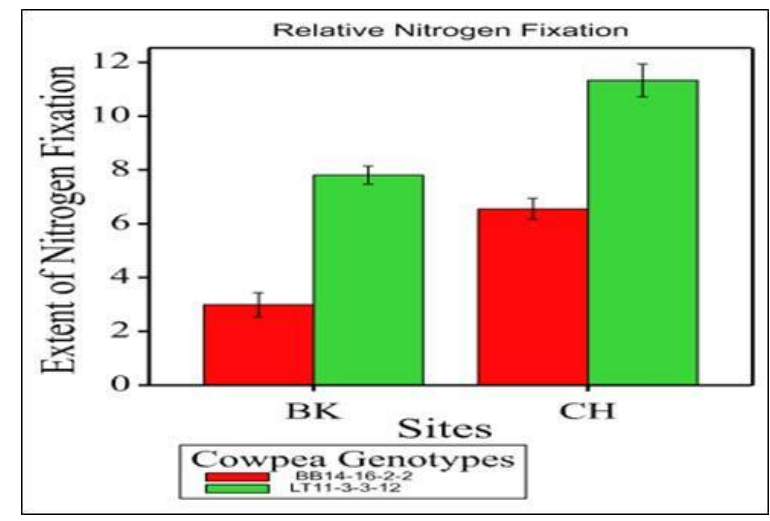

Figure 3. The Extent of Nitrogen Fixation (\%) between the two mutant genotypes over the parents at two sites

The results showed that the genetic improvement for BNF through mutation was higher for LT than BB. The results agreed with Sanginga et al. (1990) who found that there is genetic variability for N fixation among legume genotypes. However, BB could be recommended for $\mathrm{N}$ economy improvement when produced in Clay Loam soils while the LT could be used in both soil types.

\subsection{Nitrogen Derived from Atmosphere (\%Ndfa)}

The $\%$ Ndfa which was calculated from the weighted atom $\%{ }^{15} \mathrm{~N}$ ratio of nitrogen fixing plant and non-fixing plant (pearl millet) varied between sites and among cowpea genotypes. The Ndfa was 38 at Chisamba and was 70.3\% significantly $(\mathrm{P}<0.001)$ better than for Batoka site which had $12 \%$ (Figure 4 ). 


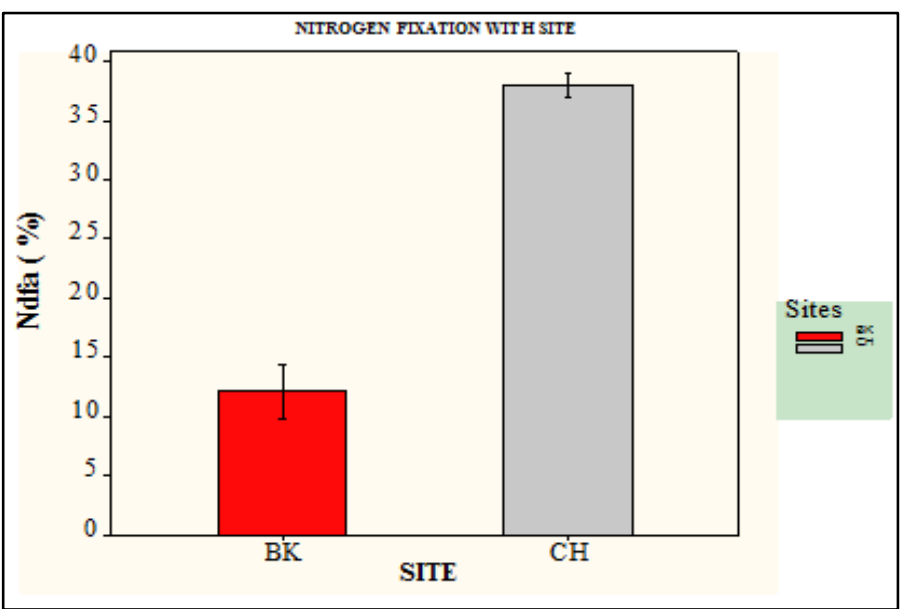

Figure 4. Proportion of nitrogen derived from the atmosphere for cowpea genotypes at two sites

Among the genotypes, LT had significant $(\mathrm{P}<0.001)$ highest nitrogen derived from atmosphere $(31.7)$ as compared to LTPRT(25.6), BB 23.0\% and BBPRT( 20.2\%) on average of two sites. An interaction was observed between the sites and genotypes. The Ndfa for BB and BBPRT were 7.0 and 3.9 at Batoka and 40.6 and 36.5 and Chisamba respectively. LT and LTPRT were however 22.2 and 17.4 at Batoka and 41.2 and 33.7 at Chisamba. Abaidoo, Dare, Killani and Opoku, (2017) found similar results where \%Ndfa among cowpea genotypes was in between 31.3 and 61.8. The results showed that the mutants BB and LT with an average of 41.0 derived more nitrogen from the atmosphere at Chisamba (Figure 5).

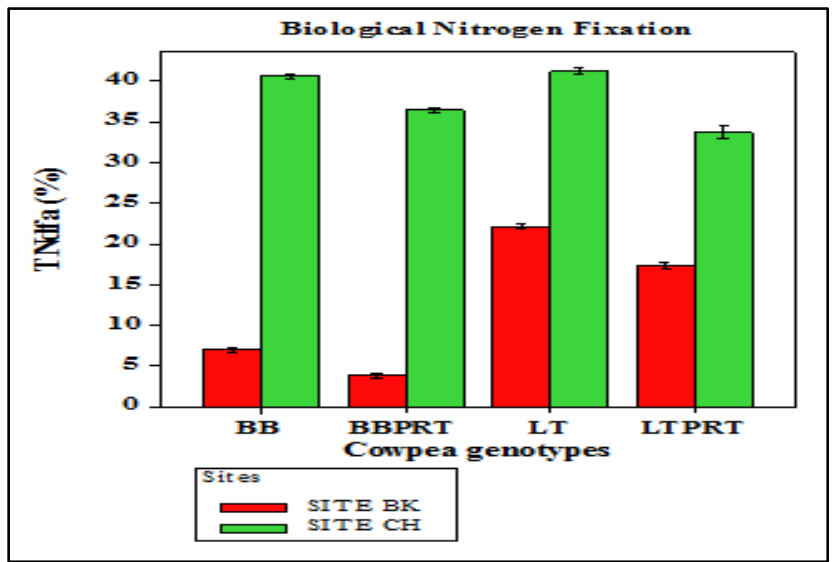

Figure 5. Total Nitrogen derived from atmosphere

BB and BBPRT were less tolerant to poor acidic soils at Batoka (table 1) compared to LT and LTPRT which appeared relatively more tolerant at Batoka. Therefore, BB could only be recommended to areas with soils that have high fertility status whereas LT could be for both sites.

\subsection{Dry Biomass Yield}

The dry biomass yield was determined mainly to calculate the total nitrogen and nitrogen fixed in the stover by the cowpea genotypes. Chisamba site produced significantly $(\mathrm{P}<0.001)$ higher dry biomass yield $\left(4932 \mathrm{~kg} \mathrm{ha}^{-1}\right)$ of cowpea genotypes than Batoka which had $1767 \mathrm{~kg} \mathrm{ha}^{-1}$ due to differences in soil quality (Table 1). On average mutants BB and LT had higher dry biomass yield of $3293 \mathrm{kgha}^{-1}$ and $3953 \mathrm{kgha}^{-1}$ than their parents BBRT and LTPRT which produced $2809 \mathrm{kgha}^{-1}$ and 3340kgha ${ }^{-1}$ respectively. The biomass yield for BB was superior over the parent at both sites while LT produced higher biomass yield than its parent LTPRT at Batoka only (Figure 6). 


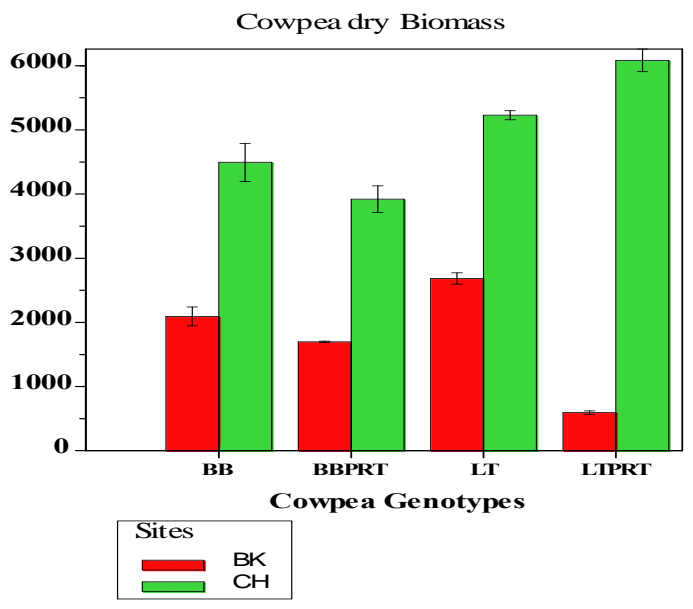

Figure 6. Dry biomass yield of the cowpea genotypes

The results suggest that high biomass yield at Chisamba would increase soil organic matter content for the benefit of the following crop in rotation as compared to Batoka with low dry biomass. Among the genotypes, LT yielded more dry biomass and this could help farmers to improve the soil fertility status if selected to be used in rotation systems at both sites. Rotation of crops increases the production of biomass necessary to the improvement of the low level of soil organic matter (Zoumana, Tatiana, Inamoud \& Marc, 2012).

The genotype that yields high dry biomass could also be promoted for livestock feeding regimes as source of protein. Schlecht, Mahler, Sangare, Susenbeth and Beeker, 1995 reported that cowpea fodder when used as feed supplement at night increased animal live weight by $95 \mathrm{~kg}$ as compared to $62 \mathrm{~kg}$ for the un-supplemented group in the dry season.

\subsection{Total Nitrogen}

Total nitrogen $(\mathrm{TN})$ was calculated from the total biomass and nitrogen content value in the dry biomass, grain and pod. The mutant LT significantly $\mathrm{P}<0.001)$ produced highest total nitrogen $\left(141.5 \mathrm{kgNha}^{-1}\right)$ as compared to LTPRT $\left(95 \mathrm{kgNha}^{-1}\right)$, while mutant BB with $103.1 \mathrm{kgNha}^{-1}$ was not significantly $(\mathrm{P}>0.05)$ superior over the BBPRT which had $100.8 \mathrm{kgNha}^{-1}$ ). LTPRT was $45 \%$ lower than its mutant LT in nitrogen accumulated in the stover, grain and pods during the cowpea plant growth period (Figure 7). An interaction between the site and cowpea genotypes on total nitrogen accumulation was found at $\mathrm{P}<0.001$ ). BB and LT mutants generally had better yields of TN at both sites whereas BBPRT and LTPRT were much higher at Chisamba.

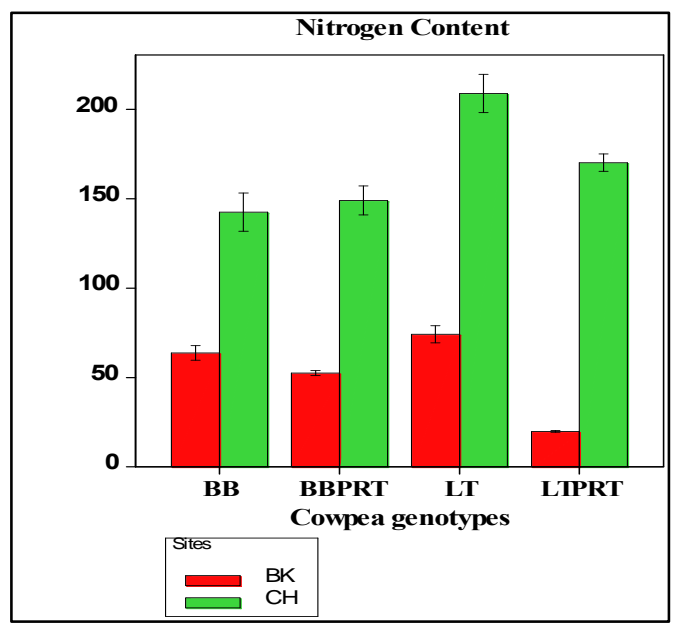

Figure 7. Total Nitrogen content in cowpea genotypes (grain, pods and dry biomass)

Total nitrogen in the dry biomass component (TNS) was $70.8 \mathrm{kgNha}^{-1}$ which represented $71.3 \%$ of the TN in the combined three plant components (biomass, grain and pod). TNS at Chisamba was $104.2 \mathrm{kgNha}^{-1}$ and that of 
Batoka was $37.5 \mathrm{kgha}^{-1}$. LT mutant that produced $93.4 \mathrm{kgNha}^{-1}$ dry biomass was significantly high at $\mathrm{P}<0.001$ followed by $\mathrm{BB}$ mutant with $68.4 \mathrm{kgNha}^{-1}$ and were both significantly superior over their parents in the TNS (Figure 8).

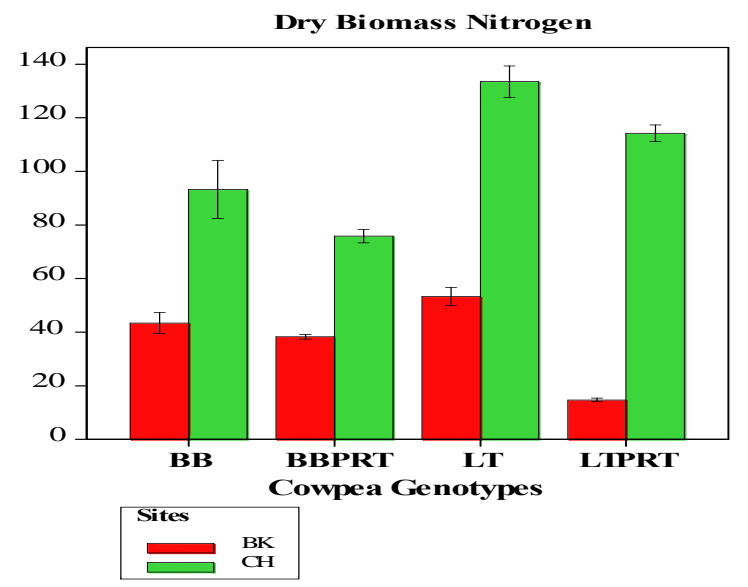

Figure 8. Nitrogen content in the cowpea total dry biomass

There was significant interaction $(\mathrm{P}<0.001)$ between the site and cowpea genotypes. This means that the sites were more favourable for specific cowpea genotypes when compared to others. Therefore, BB and LT had high yields of TNS at both sites while BBPRT and LTPRT had too low TNS at Batoka. The TNS is important on nitrogen required in plant growth because it is returned to the soil through mineralization of plant nutrients. The nitrogen in the stover could be beneficial to the succeeding cereal crop included in the rotation. The non-N benefit of cowpea rotation to cereal yields were reported to be almost always higher than after cereal crop (Jeranyama et al., 2000). Hardter, Harst, Schmidt and Frey, (1991) reported high maize yields in maize-cowpea rotation and did not show any reduction in yields over a period of growing seasons.

In the same experiment the higher maize grain yield of $12 \mathrm{tha}^{-1}$ were obtained in the maize-cowpea rotation than in the monocropping of maize which had 4.5 tha $^{-1}$ (Figure 9). The higher yields of maize were due to cowpea mutants which were superior over their parents in the amount of total nitrogen content from higher nitrogen fixation as described earlier and illustrated in Figure 8.

The study hence gave justification of why maize planted after cowpea increased maize grain yield more than in maize- maize mono-cropping system (Simunji, Munyinda, Lungu, Phiri \& Mweetwa, 2018). Cowpea genotypes had significant differences at $\mathrm{P}<0.05$ ) in maize grain yield effects where LT and BB mutants were generally superior over their parent genotypes (Figure 9).

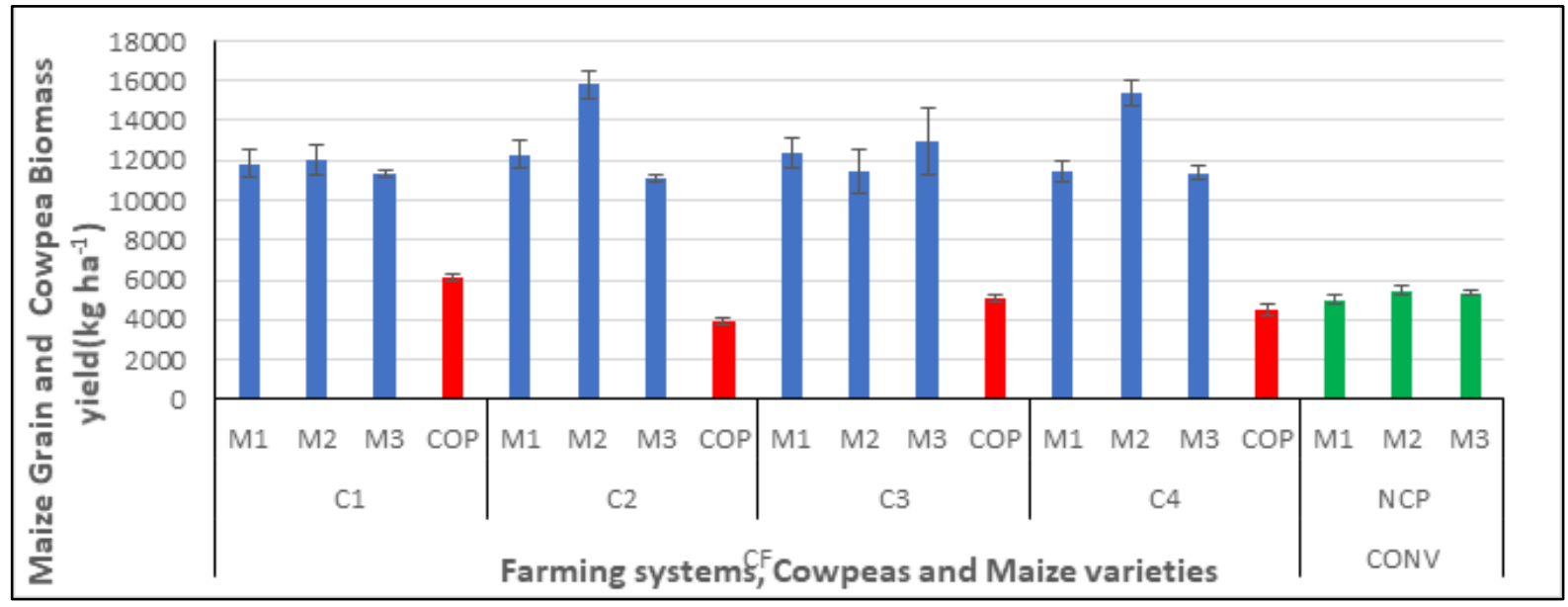

Figure 9. Effect of farming systems and Cowpea genotypes on the performance of maize. Source: Simunji, et al., 2018 


\subsection{Total Nitrogen Fixed.}

This is the total amount of nitrogen fixed in the plant stover, grain and pod as a product of nitrogen derived from atmosphere and the total $\mathrm{N}$ content. Between the two sites, Batoka (BK) had significantly lower amount of nitrogen $\left(6.6 \mathrm{kgNha}^{-1}\right)$ fixed in the plant parts $(\mathrm{P}<0.001)$ than at Chisamba $(\mathrm{CH})$ which had $63.9 \mathrm{~kg} \mathrm{~N}^{-1}$ fixed. The LT mutant genotype was significantly highest at $\mathrm{P}<0.001$ in the amount of nitrogen fixed $\left(86.1 \mathrm{~kg} \mathrm{~N} \mathrm{ha}^{-1}\right)$ at Chisamba and $16.5 \mathrm{~kg} \mathrm{~N} \mathrm{ha}^{-1}$ at Batoka (Figure 10).

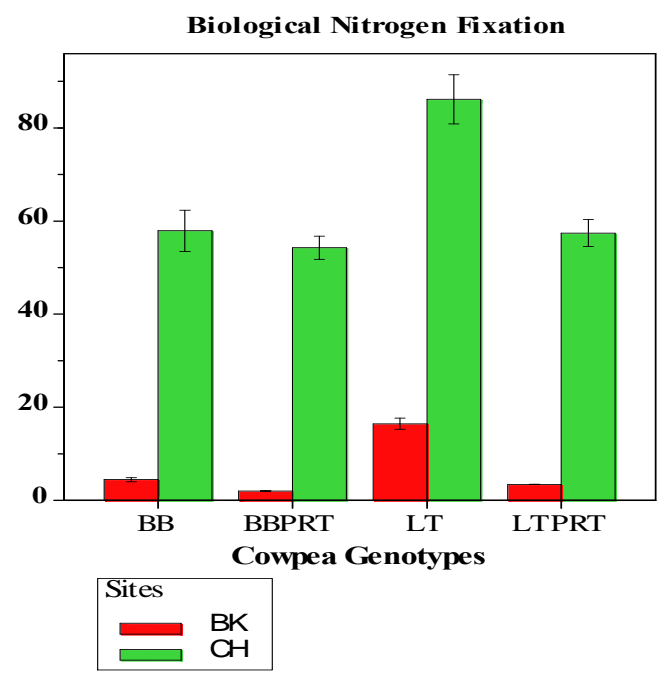

Figure 10. Total Nitrogen fixed in cowpea genotypes at Chisamba and Batoka

The general results on total nitrogen fixed were in agreement with those of Abaidoo et al. (2017) who found that total $\mathrm{N}$ fixed by cowpea genotypes was in the range of $11.9-40 \mathrm{~kg} \mathrm{~N} \mathrm{ha}{ }^{-1}$. However, Belane, Asiwe and Dakora (2011) reported the highest amount of $\mathrm{N}$-fixed by cowpea cultivar as $182 \mathrm{~kg} \mathrm{ha}^{-1}$ whereas Munjonji., Haesaert and Boeckx (2017) showed cowpea genotype with low grain yield performing better for BNF of $71 \mathrm{~kg} \mathrm{~N}^{-1}$ under well-watered and $39 \mathrm{kgN} \mathrm{ha}^{-1}$ under severe water stress.

There was a significant interaction effect at $\mathrm{P}<0.05$ between sites and genotypes of which mutant LT was observed to have greater potential of accumulated nitrogen fixed at both sites than BB. The other genotypes tended to fix more nitrogen only at Chisamba which had clay loam soils and favourable pH (5.5). BB and LT mutants had 20.5 $\mathrm{kg} \mathrm{N} \mathrm{ha}^{-1}$ and $33.4 \mathrm{~kg} \mathrm{~N} \mathrm{ha}^{-1}$ respectively fixed in the dry biomass. These were significantly $(\mathrm{P}<0.001)$ higher than BBPRT and LTPRT which had $14.6 \mathrm{~kg} \mathrm{~N} \mathrm{ha}^{-1}$ and $20.5 \mathrm{~kg} \mathrm{~N} \mathrm{ha}^{-1}$ respectively (Figure 11).

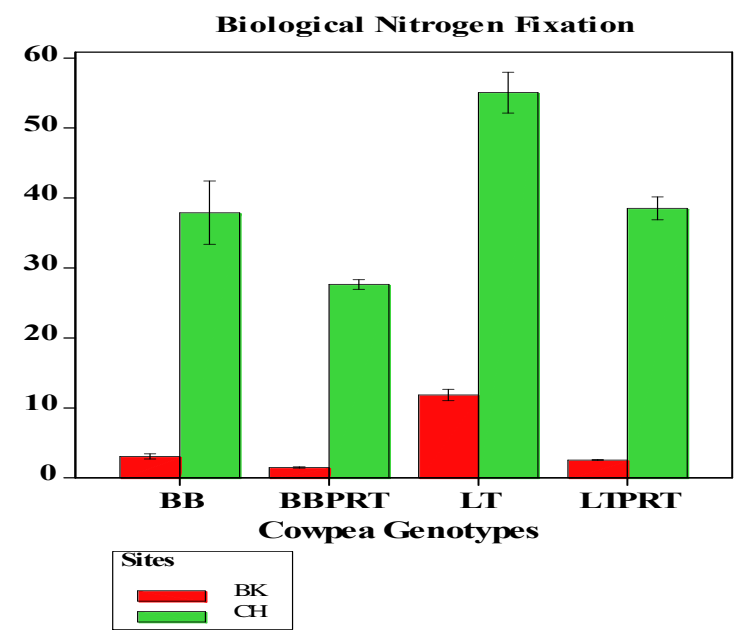

Figure 11. Total Nitrogen Fixed and partitioned to dry Biomass of cowpea grown at Chisamba and Batoka 
The amount of nitrogen fixed by the cowpea plant and partitioned to the dry biomass stover contributes to the nitrogen pool in the soil after decomposition. Part of the nitrogen in the legume plant comes from fertilizers and soil. The results were in agreement with Dakora and Keya (1997) who stated that legumes generally take more than half of their nitrogen requirement from the atmosphere and therefore take less $\mathrm{N}$ from the soil compared to the non Nfixing crops. The results further showed that dry biomass yield and biological nitrogen fixed in the biomass were significantly correlated with maize grain yield (Table 3). It was, therefore, demonstrated that cowpea could be one of the main legumes contributing to the economy of nitrogen in cropping systems.

Table 3. Regression Analysis of Variance

\begin{tabular}{llllll}
\hline Source & DF & Adj SS & Adj MS & F-Value & P-Value \\
\hline Regression & 3 & $3.09 \mathrm{E}+08$ & $1.03 \mathrm{E}+08$ & 22.43 & 0 \\
BIO & 1 & 37864526 & 37864526 & 8.24 & 0.006 \\
TNS & 1 & 18436147 & 18436147 & 4.01 & 0.052 \\
NFS & 1 & 21366591 & 21366591 & 4.65 & 0.037 \\
\hline
\end{tabular}

$$
\text { Maize grain yield }=6115+2.467 \text { Bio }-210 \text { TNS }+393 \text { NFS }
$$

The Nitrogen Harvest Index (NHI) which is the proportion of the nitrogen in the grain to the total $\mathrm{N}$ in the above ground biomass was observed lower than proportion of $\mathrm{N}$ fixed in all cowpea genotypes at Chisamba (Figure 5) and Figure 12). According to Giller and Wilson, (1995) the Nitrogen Harvest Index was lower than proportion of $\mathrm{N}$ fixed to the $\mathrm{N}$ pool of the soil. The study therefore, indicated an increased $\mathrm{N}$ pool of the soil at Chisamba as compared to Batoka soils.

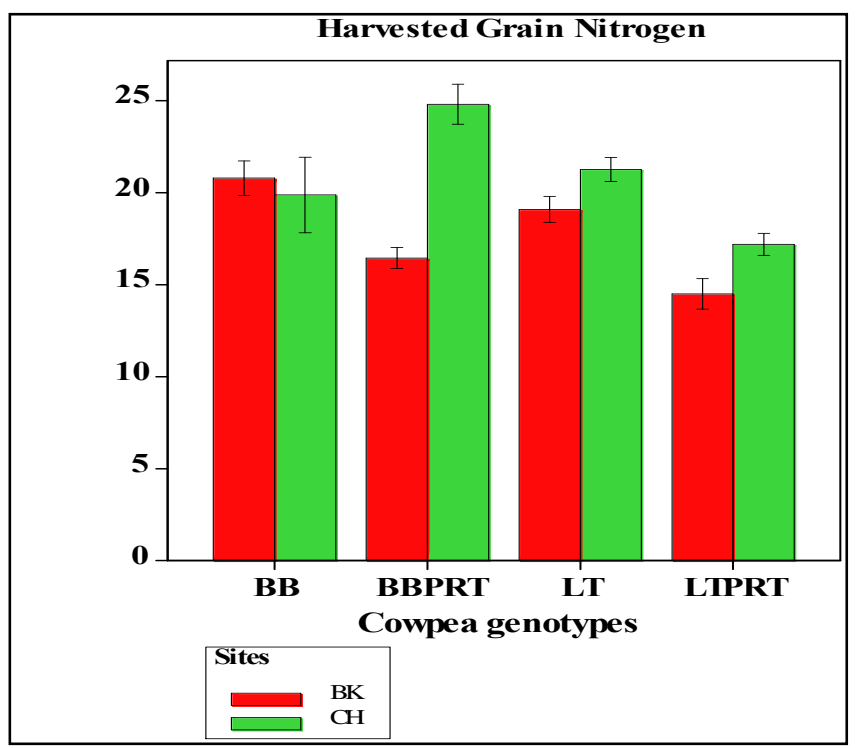

Figure 12. Nitrogen Harvest Index among Cowpea genotypes

\section{Conclusion and Recommendations}

The study on the assessment of cowpea genotypes to soil nitrogen economy made a contribution to the knowledge of Biological Nitrogen Fixation (BNF). The project confirmed that BNF by cowpea genotypes varied according to soil fertility and genotypes. Higher values of BNF were obtained in genotypes that were more tolerant to the adverse conditions such as low soil fertility and low $\mathrm{pH}$. Both BB and LT mutants were superior over their parents in terms of nitrogen derived from atmosphere, total nitrogen content and nitrogen fixed hence could be considered for integration in maize - cowpea rotation to ensure increased maize grain yields. The study further recommends that other developed mutants should also be evaluated for BNF to identify most superior genotypes with high BNF, dry biomass and nitrogen content.

\section{Acknowledgements}

I wish to convey my sincere appreciation to the Agricultural Productivity Program for Southern Africa (APPSA) for funding the study. The Golden valley Agricultural Research Trust is also appreciated for providing land and time to conduct experiments. The International Atomic Energy Agency (IAEA) is thanked for providing ${ }^{15} \mathrm{~N}$ 
labelled urea and for making arrangements to have $\% \mathrm{~N}$ and atom $\%{ }^{15} \mathrm{~N}$ analysed at the University of Florida in the United States of America (USA). I also wish to acknowledge the University of Zambia, School of Agricultural sciences (Departments of Plant Science and Soils) for their constant supervision of the project and supplying of cowpea genotypes seed used in the trials.

\section{References}

Abaidoo, R. C., Dare, M. O., Killani, S., \& Opoku, A. (2017). Evaluation of early maturing cowpea (Vigna unguiculata) germplasm for variation in phosphorus use efficiency and biological nitrogen fixation potential with indigenous rhizobial populations. Journal of Agricultural Science, 155(1), 102-116. https://dx.doi.org/10.1017/S002185961500115X

Awonaike, K. O., Kumarasinghe, K. S., \& Danso, S. K. A. (1990). Nitrogen fixation and yield of cowpea (Vigna unguiculata) as influenced by cultivar and Bradyrhizobium strain. https://doi.org/10.1016/0378-4290(90)90035

Belane, A. K., Asiwe, J., \& Dakora, F. D. (2011). Assessment of $\mathrm{N}_{2}$ fixation in 32 cowpea (Vigna unguiculata L. Walp) genotypes grown in the field at Taung in South Africa, using $15 \mathrm{~N}$ natural abundance. African Journal of Biotechnology, 10(55), 11450-11458.

Carsky, R., Oyewole, B., \& Tian, G. (1999). Integrated soil management for the savanna zone of W. Africa: legume rotation and fertilizer N. Nutrient Cycling in Agroecosystems, 55(2), 95-105. https://doi.org/10.1023/A:1009856032418

Dakora, F. D., \& Keya, S. O. (1997). Contribution of legume nitrogen fixation to sustainable agriculture in Sub-Saharan Africa. Soil Biology and Biochemistry, 29(5-6), 809-817. https://doi.org/10.1016/S0038-0717(96)00225-8

Freitas, A., Silva, A., \& Sampaio, E. (2012). Yield and biological nitrogen fixation of cowpea varieties in the semi-arid region of Brazil. Biomass and Bioenergy, 45, 109-114. https://doi.org/10.1016/j.biombioe.2012.05.017

Fujita, K., Ogata, S., Matsumoto, K., Masuda, T., Godfred, K., Ofosu-Budu, G. K., \& Kuwata, K. (1990). Nitrogen transfer and dry matter production in soybean and sorghum mixed cropping system at different population densities. Soil Sci. Plant Nutr., 36(2), 233-241. http://dx.doi.org/10.1080/00380768.1990.10414988

Giller, K. E., \& Wilson, K. J. (1995). Nitrogen Fixation in Tropical Cropping Systems. C.A.B. International Nitrogen Fixation in Tropical Cropping Systems, C.A.B. International, Wallingford, UK, 1995. Retrieved from http://library.wur.nl/WebQuery/wurpubs/16682

Hardarson, G., \& Danso, S. K. A. (1990). Use of ${ }^{15} \mathrm{~N}$ methodology to assess biological nitrogen fixation. In Hardarson G, (Ed). Use of nuclear techniques in studies of soil-plant relationships(pp. 129-160). Training course series No2. International Atomic Energy Agency, Vienna, Austria. Huergo LF.

Härdter, R., Horst, W. J., Schmidt, G., \& Frey, E. (1991). Yields and Land-Use Efficiency of Maize-Cowpea Crop Rotation in Comparison to Mixed and Mono cropping on an Alfisol in Northern Ghana. Journal of Agronomy and Crop Science, 166(5). https://doi.org/10.1111/j.1439-037X.1991.tb00922.x

IAEA (2008). Use of tracer technology in mineral fertilizer N management. In: Guidelines on Nitrogen Management in Agricultural Systems. Retrieved from https://www-pub.iaea.org/MTCD/publications/PDF/TCS-29_PDF/TCS-29.pdf

IAPRI (2015). Rural Agricultural Livelihoods survey.2015 Survey Report. Retrieved from www.iapri.org.zm/surveys.

Jeranyama, P., Oran, B. H., Waddington, S. R., \& Richard, R. H. (2000). Relay-Intercropping of Sun hemp and Cowpea into a Smallholder Maize System in Zimbabwe.

Makoi, J. H. J. R., Chimphango, S. B. M., \& Dakora, F. D. (2009). Effect of legume plant density and mixed culture on symbiotic $\mathrm{N}_{2}$ fixation in five cowpea (Vigna unguiculata L. Walp.) genotypes in South Africa. Symbiosis, 48, 57. https://doi.org/10.1007/BF03179985

Montañez, A., \& Sicardi, M. (2013). Effects of inoculation on growth promotion and biological nitrogen fixation in maize (Zea mays under greenhouse and field conditions. Laboratorio de Microbiología del Suelo, Instituto de Ecología y Ciencias Ambientales. Basic Research Journal of Agricultural Science and Review, 2, 102-110. Retrieved from http//www.basicresearchjournals.org 
Munjonji, L., Haesaert, K., \& Boeckx, P. (2017). Screening Cowpea Genotypes for High Biological Nitrogen Fixation and Grain Yield under Drought Conditions. Agronomy Journal, 110(5), 1925-1935. https://doi.org/10.2134/agronj2017.01.0037

Nwofia, G. E., Ogbonna, N. D., Agbo, C. U., \& Mbah, E. U. (2015). Growth and Yield of Some Vegetable Cowpea Genotypesas Influenced by Planting Season. International Journal of Agriculture and Forestry, 5(3), 205-210.

Phiri, E. A. C., \& Chabala, I. (2006). Policy frame work for promoting land and water management technologies. In land and water management in southern Africa towards sustainable agriculture. Proceedings of the inaguaral scientific symposium of the SADC land and water management Applied research and Training programme held in Lilongwe, Malawi on the $14-16^{\text {th }}$ February, 2006. Edited by Calvin Nhira, Alfred Mapiki and Patrick Rankhumise. pp. 97-105.

Sanginga, N., Lyasse, O., \& Singh, B. B. (1990). Phosphorus use efficiency and nitrogen balance of cowpea breeding lines in a low P soil of the derived savanna zone in West Africa. Plant and Soil, 220(1-2), 119-128. https://doi.org/10.1007/BF00032244

Schlecht, E., Mahler, F., Sangare, M., Susenbeth, A., \& Beeker, K. (1995). Quantitative and qualitative estimation of nutrient intake and faecal excretion of Zebu cattle grazing natural pasture in semi-arid Mali. Retrieved from http://agris.fao.org/agris-search/search

Senaratne, R., Liyanage, N. D. L., \& Soper, R. J. (1995). Nitrogen fixation of and N transfer from cowpea, mungbean and groundnut when intercropped with maize. Fertilizer Research, 40, 41. https://doi.org/10.1007/BF00749861.

Simunji, S., Munyinda, K., Lungu, O., Mweetwa, O. A., \& Phiri, E. (2018). Optimizing Soil moisture and Nitrogen Use efficiency of Some Maize (Zea mays) Varieties under Conservation Farming system. Sustainable Agriculture Research, 7(4), 42-50. https://doi.org/10.5539/sar.v7n4p42

Singh, B. B., Ajeigbe, H. A., Fernandez, S. A., \& Abubakar, M. (2003). Improving the production and utilization of cowpea as food and fodder. Field Crops Research, 84(1-2), 169-177. https://doi.org/10.1016/S0378-4290(03)00148-5

Zoumana, K., Tatiana, K., Inamoud, I. Y., \& Marc, N. (2012). Effects of Cropping System and Cowpea Variety on Symbiotic Potential and Yields of Cowpea (Vigna unguiculata L. Walp) and Pearl Millet (Pennisetum glaucum L.) in the Sudano-Sahelian Zone of Mali. International Journal of Agronomy, 2012, 8. https://doi.org/10.1155/2012/761391

VSN International (2015). GenStat for Windows 14th Edition. VSN International, Hemel Hempstead, UK. Web page: GenStat.co.uk. Retrieved from https://www.vsni.co.uk/software/genstat/htmlhelp/server/HCITEGEN.htm

\section{Copyrights}

Copyright for this article is retained by the author(s), with first publication rights granted to the journal.

This is an open-access article distributed under the terms and conditions of the Creative Commons Attribution license (http://creativecommons.org/licenses/by/3.0/). 